RESEARCH ARTICLE

\title{
Socio-Economic Impact of Hybrid Castor - (YRCH 1) among Salem and Namakkal Castor Farmers
}

\author{
Naveena $\mathrm{D}^{* 1}$, Srivara Buddhi Bhuvaneswari $\mathrm{S}^{1}$, Shibi Sebastian ${ }^{1}$ and Patil $\mathrm{SG}^{2}$ \\ ${ }^{1}$ Department of Agricultural Extension \& Rural Sociology, Tamil Nadu \\ Agricultural University, Coimbatore-641 003
}

${ }^{2}$ Department of Physical Sciences and Information Technology, Tamil Nadu Agricultural University, Coimbatore-641 003.

Corresponding author Mail Id : naveenadharmaraj3@gmail.com

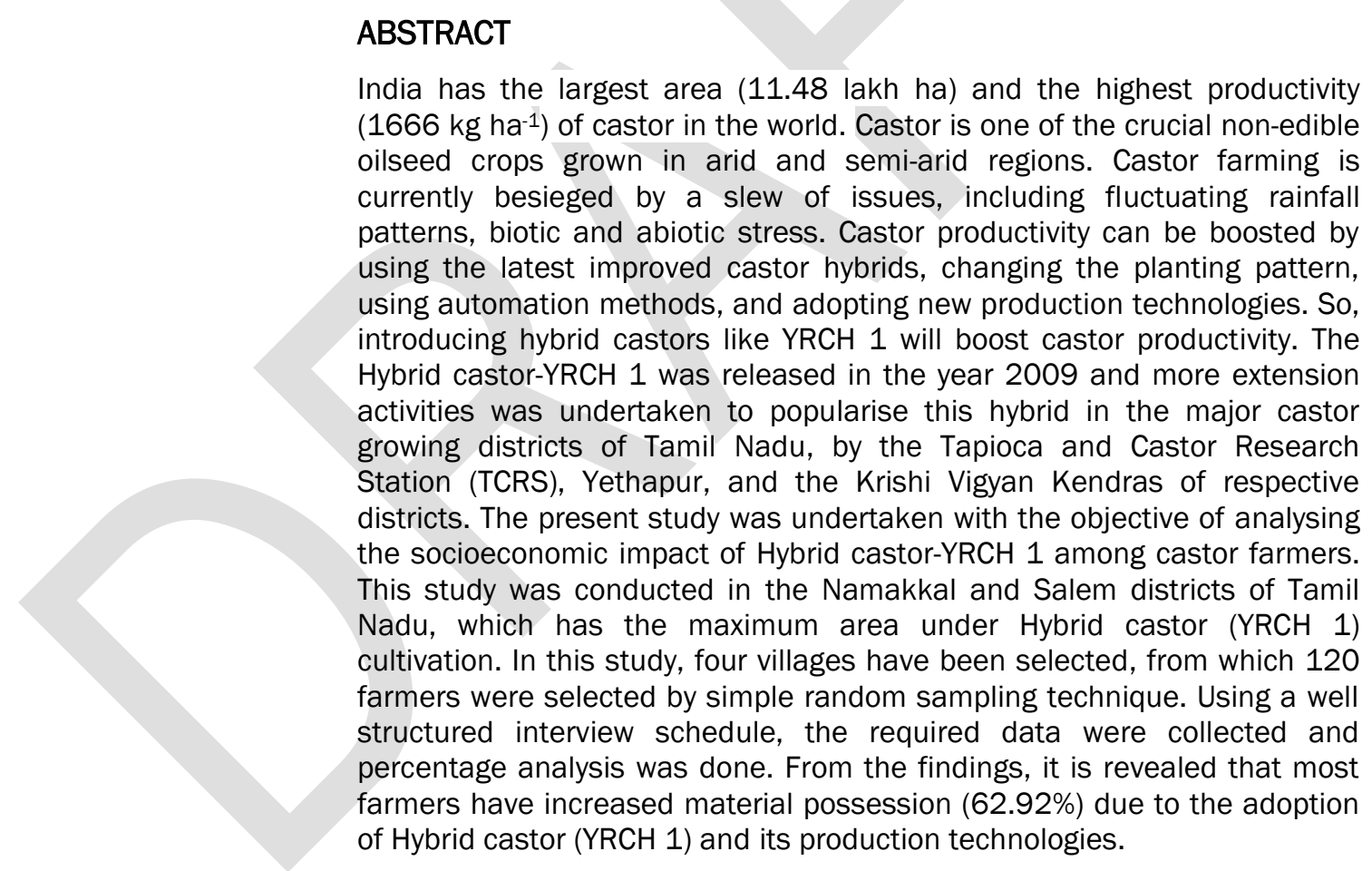

Keywords: Hybrid Castor; YRCH 1; Socio Economic Impact.

\section{INTRODUCTION}

At the National level, average castor seed productivity for $2019-20$ is estimated to be $2,052 \mathrm{~kg} \mathrm{ha}^{-1}$ compared to $1,407 \mathrm{~kg} \mathrm{ha}^{-1}$ last year. The average yield findings are based on farmers' responses about 
their yield expectations on present crop conditions (Business Standard, February 22, 2020). India is currently the top producer in the world, followed by China and Brazil. Castor seed contains 45-47 per cent non-edible oil, which is used for domestic, medicinal, and industrial purposes (M.M. Desale et al., 2011). It is a widespread culinary, medicine, and skin-care ingredient and an industrial lubricant and biodiesel fuel component. Castor oil is highly prized for its termite-repelling abilities. It is the only commercial source of a hydroxylated fatty acid; the oil generated from this crop is considered essential to the global specialty chemical sector. Castor seed production had increased from 11.97 lakh tonnes in 2018-19 to 20.60 lakh tonnes in 2019-20,. The output of castor oil in this country varies between 250,000 and 350,000 tonnes per year. Castor crops can be cultivated in various soil types as long as they are deep and well-drained. However, farmers in arid and semi-arid areas of Tamil Nadu decided that castor was no longer a profitable crop (Hema, 2018). Hence, the castor cultivation area decreased. To solve this problem, a high-yielding, drought-resistant cultivar castor hybrid $\mathrm{YRCH} 1$ suitable for both rainfed and irrigated situations was developed, and the state variety release committee approved the same for cultivation throughout Tamil Nadu in 2009. So, it was felt that introducing Hybrid castors like YRCH 1 would boost castor productivity. Transfer of technology measures was undertaken to popularise this hybrid in the major castor growing districts of Tamil Nadu such as Salem, Namakkal, Perambalur, Trichy, Kallakurichi, Dharmapuri, Erode, Cuddalore, and other districts by the Tapioca and Castor Research Station (TCRS), Yethapur and the Krishi Vigyan Kendras of respective districts. Interestingly, during the year 2019 to 2020 alone, TCRS, Yethapur distributed $15141 \mathrm{Kgs}$ of Hybrid Castor seeds to cultivate an area of 4757 hectares with a monetization value of Rs. 59.43 Crores (Anonymous, 2020). The main reason to release a hybrid or variety is to increase the crop yield by reducing the cost of cultivation. If that, farmers' income would raise, which leads to an increase in the socio-economic status and thereby ensuring livelihood security. Keeping this in view, the present study was done with the goal of determining the socioeconomic impact of farmers owing to the adoption of Hybrid castor-YRCH 1.

\section{MATERIAL AND METHODS}

The present study was conducted in the Mallasamudram block of Namakkal district and the Edappadi block of Salem district, representing the maximum area under Hybrid castor-YRCH 1 cultivation compared to other blocks of these two districts. On consideration of the highest area under Hybrid castor (YRCH 1) cultivation, the list of villages was obtained from Tapioca and Castor research station, Yethapur. From the list of villages, two villages from the Mallasamudram block and two villages from the Edappadi block were selected based on the maximum area under the Hybrid castor-YRCH 1. From the selected four villages, 30 castor growers were selected by simple random sampling technique. Thus, the sample size will be 120 castor growers.

The information regarding the study was obtained through a well-structured interview schedule. socioeconomic impact refers to a measure of how far the economic activity and social life has changed due to the adoption of Hybrid castor (YRCH 1) among the farming community. Socio-economic Impact was measured under five major domains like changes that occurred in their farm, material, descendants, economic and social interaction. In this study, the maximum possible score for the changes in socioeconomic impact was 81. Percentage analysis was used for analyzing the socio economic impact of the farmers due to the adoption of Hybrid castor (YRCH 1) growers.

\section{RESULTS AND DISCUSSION}

This study is essential to know about the social and economic changes that have occurred after adopting the recommended technologies of Hybrid castor-YRCH 1. To assess the socio economic impact, necessary data were collected and findings are presented in Fig. 1 and Table 1.

\section{Overall socio-economic Impact due to adoption of Hybrid castor-YRCH 1}

Results of the spread of Castor growers according to their overall socio-economic impact due to the adoption of Hybrid castor-YRCH 1 are given in Fig 1. It includes five major changes, namely farm change, material change, economic change, descendants change, and social change.

Fig 1: Overall distribution of respondents according to their socio economic Impact due to adoption of Hybrid Castor (YRCH 1) growers. 


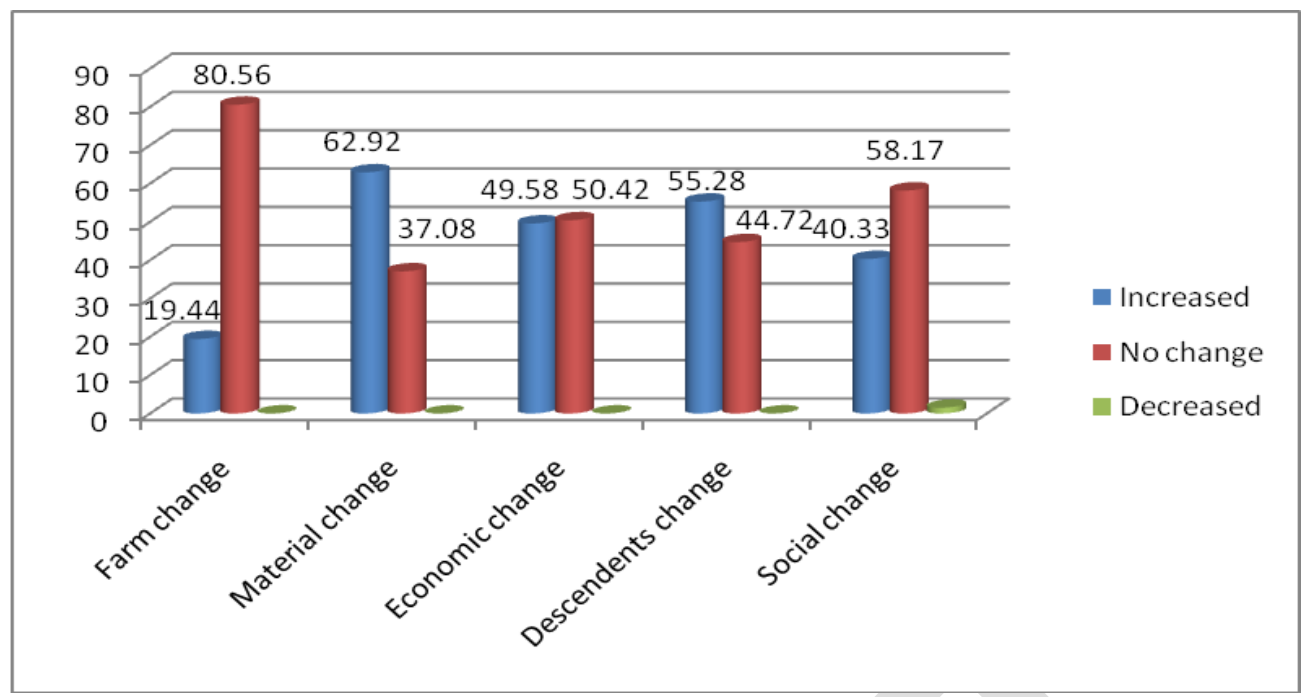

Fig 1 indicates that among the five domains of changes due to the adoption of recommended practices of Hybrid castor (YRCH 1), material change has increased to a tune of 62.92 per cent compared to other socio-economic changes. This is due to the reason that their basic daily needs were covered under the material change domain. This is followed by increased descendants change $(55.28 \%)$, which is necessary for the family that includes health, education and religious activities. This is followed by economic change $(49.58 \%)$ and social change (40.33\%). And the increase in farm change (19.44\%) is quite less compared to other changes because purchasing land, livestock and digging bore wells require more money. It happens very rarely, often single-time activity and is performed only when farmers have more money and very essential. The potential income-related impacts include changes in inputs use, associated costs; output (quantity and quality); and gross income. Some farmers could experience changes in the time available for conducting off-farm income-generating activities. A farm's efficiency could deteriorate or improve with the use of new technologies impacting the farmer's income (Garcia-Yi et al., 2014)

\section{Specific socio-economic Impact due to adoption of Hybrid castor-YRCH 1}

Specific socio economic impact of all five domains is given in Table 1.

Table 1: Specific socio-economic impact perceived by the respondents as a result of the adoption of Hybrid castor (YRCH1).

\begin{tabular}{|c|c|c|c|c|c|c|c|}
\hline \multirow{3}{*}{ S.No } & & \multicolumn{6}{|c|}{ Change indicators } \\
\hline & Particulars & \multicolumn{2}{|c|}{ Increased } & \multicolumn{2}{|c|}{ No change } & \multicolumn{2}{|c|}{ Decreased } \\
\hline & & No & $\%$ & No & $\%$ & No & $\%$ \\
\hline \multicolumn{8}{|c|}{ A. Farm change } \\
\hline 1. & Purchased new lands & 16 & 13.3 & 104 & 86.7 & - & - \\
\hline 2. & Improved the existing land & 28 & 23.3 & 92 & 76.7 & - & - \\
\hline 3. & Leased in lands for cultivation & - & - & 120 & 100.0 & - & - \\
\hline 4. & Leased out lands for cultivation & - & - & 120 & 100.0 & - & - \\
\hline 5. & Deepened the existing wells/ bore wells & 5 & 4.2 & 115 & 95.8 & - & - \\
\hline 6. & Dug new well/bore well & 2 & 1.7 & 118 & 98.3 & - & - \\
\hline 7. & Purchased new machineries & 29 & 24.2 & 91 & 75.8 & - & - \\
\hline 8. & Purchased new tools/equipment & 45 & 37.5 & 75 & 62.5 & - & - \\
\hline 9. & Purchased additional livestock & 85 & 70.8 & 35 & 29.2 & - & - \\
\hline \multicolumn{8}{|c|}{ B. Material possession } \\
\hline
\end{tabular}




\begin{tabular}{|c|c|c|c|c|c|c|c|}
\hline 1. & Purchased new utensils & 87 & 72.5 & 33 & 27.5 & - & - \\
\hline 2. & Purchased household appliances & 94 & 78.3 & 26 & 21.7 & - & - \\
\hline 3. & Purchased new jewels & 80 & 66.7 & 40 & 33.3 & - & - \\
\hline 4. & Purchased new vehicle & 69 & 57.5 & 51 & 42.5 & - & - \\
\hline 5. & Purchased TV, Radio, Phone, Tape, etc & 89 & 74.2 & 31 & 25.8 & - & - \\
\hline 6. & Renovation of house & 34 & 28.3 & 86 & 71.7 & - & - \\
\hline \multicolumn{8}{|c|}{ C. Descendants change } \\
\hline 1. & Provided higher education to their children & 40 & 33.3 & 80 & 66.7 & - & - \\
\hline 2. & Had better health care and nutritious food & 90 & 75.0 & 30 & 25.0 & - & - \\
\hline 3. & Spent more for social activities & 42 & 35.0 & 78 & 65.0 & - & - \\
\hline \multicolumn{8}{|c|}{ D. Economic change } \\
\hline 1. & Repayment of loans & 76 & 63.3 & 44 & 36.7 & - & - \\
\hline 2. & Increased savings and deposits & 56 & 46.7 & 64 & 53.3 & - & - \\
\hline 3. & More money invested in farming & 67 & 55.8 & 53 & 44.2 & - & - \\
\hline \multicolumn{8}{|c|}{ E. Social change } \\
\hline 1. & Extension contact & 56 & 46.7 & 64 & 53.3 & - & - \\
\hline 2. & Organization participation & 76 & 63.3 & 44 & 36.7 & - & - \\
\hline 3. & Opinion leader & 19 & 15.8 & 95 & 79.2 & 6 & 5.0 \\
\hline 4. & Emerged as a leader & 13 & 10.8 & 104 & 86.7 & 3 & 2.5 \\
\hline 5. & Increased outside contact & 78 & 65.0 & 42 & 35.0 & - & - \\
\hline
\end{tabular}

Table 1 consists of the specific socio-economic impact of all five changes. Among the five, material possession has a marked and increased change. In material change, two factors have increased i.e., purchasing household appliances $(94.0 \%)$ and purchasing TV, phone, radio (89\%). Because household appliances were much essential for everyday life and communication gadgets ve become the basic needs for information receiving and sharing, farmers tend to purchase the above-said items when they have more resources at their disposal.

This is followed by descendants change, wherein 90 per cent of the respondents spent more on better health care and nutritious food. This may be due to more concern about their health. Economic change occupies the third rank in socio-economic impact, where there is an increase (76\%) of repayment of loans so that the interest-paying duration will be reduced to upgrade the lifestyle of the family. From the previous study done by (Sudha et al., 2006), it was shown that repayment of loans was the third most increased socio-economic change compared to overall changes. Fourth comes the social change, in which outside contact $(65.0 \%)$ and participation in the organization (63.3\%) have been found to be increased. From the social change, it is noticed that people developed more contact in society after adopting Hybrid castor. Increased outside contact will gain farmers to have more exposure to the upcoming technologies. Hence, it is visible from the result that farmers have good outside contact, making themgain more knowledge. Last comes the farm change, where a huge increase in purchasing of additional livestock (70.8\%) is observed. 
The reason for this outcome is livestock provide regular and additional income daily or continuously. It has emerged as a primary source of support for arid and semi arid farmers. So the farmers in this region with their increased income through the cultivation of Hybrid castor-YRCH 1, the farmers in this region have invested it in livestock possession to get daily returns from animal produce for meeting their day-today needs. Lucia Omobolanle et al., (2005) concluded that maize technologies had contributed significantly to some dimensions of members' well-being and if technologies are adopted sustained with full use of recommended inputs, it can alleviate the problems of peasant farmers and will boost food production, as well as meeting the goal of being self-sufficient in food supply to the ever-increasing population. Therefore, agricultural technologies developed and disseminated should meet farmers' socio-economic and environmental changing situations.

\section{CONCLUSION}

From the findings of the study, it is revealed that the majority of the respondents have increased material possession in the socio-economic impact category. And there is an increase in their socio-economic level in all five domains. Therefore, it is visible from the result that there is a positive socio-economic impact by adopting Hybrid castor (YRCH 1). Hence, more awareness programmes and training can be conducted to popularise and create a positive attitude towards Hybrid castor-YRCH 1 among non-adopters to ensure livelihood security in Tamil Nadu.

\section{REFERENCES}

Desale, M. M., Badhe, D. K., and R. C. Patel. 2011. Knowledge level of hybrid castor growers regarding its production technology. Ag. Update., 6(2); 14-16.

Garcia-Yi, J., Lapikanonth, T., Vionita, H., Vu, H., Yang, S., Zhong, Y., and Wesseler, J. 2014. What are the socio-economic impacts of genetically modified crops worldwide? A systematic map protocol. Environ. Evid., 3(1);1-17.

Hema, P. 2018. Adoption of recommended castor hybrid production technology among the castor growers of Tamil Nadu. EPRA Int. j. res. dev. (IJRD).,3 (10).

Lucia Omobolanle, O., Samuel Olu, E., and Adebiyi Gabriel, D. 2005. Socio-Economic Impact Assessment Of Maize Production Technology On Farmers' welfare In Southwest, Nigeria. J. Cent. Eur. Agric., 6(1); 15-26.

Sudha, M., Gajanana, T. M., and D. S. Murthy. 2006. Economic impact of commercial hybrid seed production in vegetables on farm income, employment and farm welfare-A case of tomato and okra in Karnataka. Agric. Econ. Res. Rev. ,19(347-2016-16782): 251-268. 